\title{
Effects of 0.2 ppm ozone on biomarkers of inflammation in bron- choalveolar lavage fluid and bronchial mucosa of healthy subjects
}

\author{
M.T. Krishna*, J. Madden*, L.M. Teran*, G.L. Biscione*, L.C.K. Lau*, N.J. Withers*, T. Sandström+, \\ I. Mudway , F.J. Kelly
}

Effects of 0.2 ppm ozone on biomarkers of inflammation in bronchoalveolar lavage fluid and bronchial mucosa of healthy subjects. M.T. Krishna, J. Madden, L.M. Teran, G.L. Biscione, L.C.K. Lau, N.J. Withers, T. Sandström, I. Mudway, F.J. Kelly, A. Walls, A.J. Frew, S.T. Holgate. @ERS Journals Ltd 1998.

ABSTRACT: Short-term exposure to ozone at peak ambient levels induces neutrophil influx and impairs lung function in healthy humans.

In order to investigate the mechanisms contributing to neutrophil recruitment and to examine the role of T-cells in the acute inflammatory response, we exposed 12 healthy humans to 0.2 parts per million ( $\mathrm{ppm}$ ) of ozone and filtered air on two separate occasions for $2 \mathrm{~h}$ with intermittent periods of rest and exercise (minute ventilation=30 L·min'1). Fibreoptic bronchoscopy was performed $6 \mathrm{~h}$ after the end of exposures. Total protein, tryptase, histamine, myeloperoxidase, interleukin (IL)-8 and growth-related oncogene- $\alpha($ Gro- $\alpha)$ were measured and total and differential cell counts were performed in bronchoalveolar lavage (BAL) fluid. Flow cytometry was performed on BAL cells to study total T-cells, T-cell receptors $(\alpha \beta$ and $\gamma \delta)$, T-cell subsets (CD4+ and CD8+ cells) and activated T-cell subsets (CD25+). Using immunohistochemistry, neutrophils, mast cells, total T-cell numbers, T-cell subsets, CD25+ T-cells and leukocyte endothelial adhesion molecules including P-selectin, E-selectin, intercellular adhesion molecule (ICAM)-1 and vascular adhesion molecule (VCAM)-1 were quantified in the bronchial biopsies.

Paired samples were available from nine subjects. Following ozone exposure there was a threefold increase in the proportion of polymorphonuclear neutrophils (PMNs) $(p=0.07)$ and epithelial cells $(p=0.05)$ in BAL fluid. This was accompanied by increased concentrations of IL-8 $(p=0.01)$, Gro- $\alpha(p=0.05)$ and total protein $(p=0.058)$. A significant positive correlation was demonstrated between the two chemokines and proportion of PMNs in BAL fluid. After ozone exposure there was a significant decrease in the $\mathrm{CD} 4 / \mathrm{CD8}$ ratio $(p=0.05)$ and the proportion of activated $\mathrm{CD4}+(\mathrm{p}=0.01)$ and CD8+ T-cells $(p=0.04)$. However, no significant changes were demonstrable in any of the inflammatory markers studied in the biopsies.

Short-term exposure of healthy humans to $0.2 \mathrm{ppm}$ ozone induced a neutrophil influx in peripheral airways at $6 \mathrm{~h}$ post exposure, but no apparent inflammatory response in proximal airways. This response seems to be mediated at least in part by interleukin-8 and growth-related oncogene- $\alpha$.

Eur Respir J 1998; 11: 1294-1300.
*University Medicine, Southampton General Hospital, University of Southampton, UK. 部e Rayne Institute of Cardiovascular Research, St Thomas' Hospital, London, UK. +National Institute of Working Life, University of North Sweden, Umeå, Sweden.

Correspondence: M.T. Krishna

University Medicine

Level D, Centre block

Southampton General Hospital

Tremona Road

Southampton SO16 6YD

UK

Fax: 441703701771

Keywords: Air Pollution

chemokines

inflammation

ozone

T-cells

Received: August 191997

Accepted after revision March 71998

This study was funded by the Medical Research Council (UK), British Lung Foundation, Pearl Assurance and European Concerted Action Grant. GLB was funded by MURST, Italy.
Several studies evaluating the effects of ozone on healthy as well as asthmatic subjects have shown that short-term exposure to $0.08-0.40$ parts per million (ppm) ozone impairs lung function and induces an acute inflammatory response [1-3]. These studies have reported an influx of polymorphonuclear neutrophils (PMNs) and secretion of interleukins (IL)-6 and 8, granulocyte macrophage colony stimulating factor (GM-CSF), total protein, albumin, fibronectin and complement $\mathrm{C} 3 \mathrm{a}$ [1-3].

Endothelial adhesion molecules are considered to play a key role in leukocyte recruitment in an inflammatory response. The first step in that recruitment process involves the upregulation of P- and E-selectins (CD62 P and $\mathrm{E})$, which mediate the early adhesion and "rolling" of leukocytes on the vessel wall [4]. Depending on the stimulus, there then occurs an upregulation of a second set of adhesion molecules belonging to the immunoglobulin superfamily including intercellular adhesion molecule-1 (ICAM-1, CD54) and vascular cell adhesion molecule-1 (VCAM-1, CD106) on the vessel wall, which interact with their counterligands on the leukocyte surface: leukocyte functional antigen (LFA-1, CD11a/CD18) and very late antigen (VLA4, CD49d/CD29), respectively. This leads to firm adhesion, leukocyte priming, and transmigration of the leukocyte from the intravascular compartment to the extravascular space [4].

It has been shown previously that short-term exposure to $0.12 \mathrm{ppm}$ ozone induces rapid upregulation of P-selectin in the microvascular endothelium of healthy bronchial submucosa and that this represents one of the earliest 
events in the inflammatory response to ozone [5]. The present study was carried out to examine the inflammatory effects of short-term exposure to $0.2 \mathrm{ppm}$ ozone on healthy human airways at a later point $(6 \mathrm{~h}$ after the end of exposure). Based on the above model of leukocyte recruitment, it is likely that some of the key steps involved in neutrophil influx take place at this time point, including the release of chemoattractants such as IL-8 and growthrelated oncogene- $\alpha$ (Gro- $\alpha$ ) and the upregulation of endothelial adhesion molecules. E-selectin and ICAM-1, in particular have been linked to neutrophil recruitment under other circumstances [6]. In addition, a recent study [7] has suggested that T-cells could play a regulatory role in the acute inflammatory response to ozone and the present study examines this hypothesis.

\section{Subjects and methods}

Details of the experimental design, subjects, ozone exposure and fibreoptic bronchoscopy have been described previously [8]. In brief, 12 healthy, nonsmoking young adults ( 10 males and two females, age $27.6 \pm 6.2$ yrs (mean $\pm S D)$ ) were recruited into the study. A written informed consent was obtained from all subjects and this study received the approval of Southampton University and Hospitals Joint Ethics Committee. A detailed medical history was obtained from all subjects and a physical examination performed at screening. None of the subjects had any history of allergies or asthma, or any history of respiratory tract infection for at least 6 weeks before the study days. Exposures were carried out under controlled conditions with a temperature of $25^{\circ} \mathrm{C}$ and relative humidity of 40 $60 \%$. All subjects were exposed to $0.2 \mathrm{ppm}$ ozone and filtered air for $2 \mathrm{~h}$ in a randomized, double-blind, cross-over control fashion. During the exposures the volunteers were subjected to intermittent $15 \mathrm{~min}$ alternating cycles of rest and exercise (minute ventilation $\left.=30 \mathrm{~L} \cdot \mathrm{min}^{-1}\right)$. The average ozone concentration during the exposures was $0.199 \pm 0.009$ ppm (mean \pm SD). None of the subjects had received any form of anti-inflammatory drugs, antihistamines or dietary antioxidant supplementation. Fibreoptic bronchoscopy was performed $6 \mathrm{~h}$ after the end of exposures. Bronchoalveolar lavage (BAL) was performed using 160 $\mathrm{mL}$ prewarmed $\left(37^{\circ} \mathrm{C}\right)$ saline in the right upper lobe and left upper lobes on days 1 and 2, respectively, and bronchial mucosal biopsies were obtained from proximal airways as described previously [8]. Paired samples were obtained from only nine subjects, because one subject had a $39 \%$ drop in the forced expiratory volume in one second (FEV1) following ozone exposure and was considered unsuitable for bronchoscopy, one subject was unable to tolerate bronchoscopy at all (ozone day) while another underwent bronchoscopy after filtered air exposure, became dist-ressed $3 \mathrm{~h}$ after bronchoscopy, was observed overnight in hospital and was subsequently withdrawn from the study.

\section{Analysis of mediators in bronchoalveolar fluid}

BAL fluid samples were filtered through a $100 \mu \mathrm{m}$ filter (Becton-Dickinson, Oxford, UK), centrifuged at $300 \times \mathrm{g}$ for $10 \mathrm{~min}$ and cells washed once in sterile phosphate-buf-fered saline (PBS). Cells were counted using trypan blue exclusion of dead cells on a Neubauer haemo- cytometer (BDH, Dagenham, UK), and an aliquot was separated for cytospin preparation and fluorescence-activated cell scan (FACS) analysis. Cytospin preparations were prepared using a Shandon cytospin device (Shandon Southern Instruments, Runcorn, UK). The slides were air dried and differential cells counts were performed after staining with a rapid Giemsa stain (HemaGurr, BDH, Poole, UK) with at least 400 cells being counted. BAL fluid supernatant was aliquoted and stored at $-70^{\circ} \mathrm{C}$ for mediator analysis.

Mediators were measured in BAL fluid supernatant using the following methods. The total protein assay was carried out by modification of the LowRY method [9], proposed by Sмiтн et al. [10], which measures protein by spectrophotometery at $562 \mathrm{~nm}$.

Myeloperoxidase, histamine and tryptase were measured by radioimmunoassay (RIA) using commercially available kits (Pharmacia, Uppsala, Sweden). The sensitivities of the assays were $8 \mu \mathrm{g} \cdot \mathrm{mL}^{-1}, 0.1 \mathrm{ng} \cdot \mathrm{mL}^{-1}$ and $0.5 \mathrm{ng} \cdot \mathrm{mL}^{-1}$, respectively.

Total IL-8 was measured by enzyme-linked immunosorbent assay (ELISA) (PeliKine Compact, human IL-8 ELISA kit; CLB, Amsterdam, The Netherlands) with a sensitivity of $1 \mathrm{pg} \cdot \mathrm{mL}^{-1}$.

Gro- $\alpha$ was measured using a commercially available ELISA kit (R\&D systems, Abingdon, UK) with a sensitivity of $15 \mathrm{pg} \cdot \mathrm{mL}^{-1}$.

Immunohistochemistry. Two biopsies were obtained from proximal airways, fixed overnight in acetone containing protease inhibitors, and processed into glycol methacrylate on the following day as described previously $[6,11]$. Sections $(2 \mu \mathrm{m}$ thick) were cut using a microtome (Supercut 2065, Leica, Germany), floated on to ammonia water (1:500), then picked on to glass slides coated with $0.01 \%$ poly-L-lysine and allowed to dry at room temperature for 1-4 h. Sequential $2 \mu \mathrm{m}$ sections were taken for adhesion molecules and pan-vessel marker endothelium clone (EN)4 and for CD4, CD8 and CD25. Immunostaining by the avidin biotinylated complex (ABC) method was performed using the standard protocol in our laboratory, as des-

Table 1. - Monoclonal antibodies used for immunohistochemistry

\begin{tabular}{|c|c|c|c|}
\hline Name & Marker & Cells & Source \\
\hline CD3 & CD3 & T-cells & $\begin{array}{l}\text { DAKO* } \\
\text { Becton Dickinson }{ }^{+}\end{array}$ \\
\hline CD4 & CD4 & T-cells & DAKO* \\
\hline CD8 & CD8 & T-cells & A. Walls" \\
\hline AA1 & Tryptase & Mast cells & $\begin{array}{l}\text { DAKO* } \\
\text { DAKO* }\end{array}$ \\
\hline $\mathrm{NE}$ & Elastase & Neutrophils & \\
\hline CD25 & $\begin{array}{l}\text { T-lympho- } \\
\text { cyte }\end{array}$ & $\begin{array}{l}\text { Activated } \\
\text { T-lymphocyte }\end{array}$ & Sanbio \\
\hline EN4 & $\begin{array}{l}\text { Endothel- } \\
\text { ium }\end{array}$ & $\begin{array}{l}\text { Pan-endothelial } \\
\text { marker }\end{array}$ & Serotec $\$$ \\
\hline $\begin{array}{l}\text { ICAM-1 } \\
\text { (RR1) }\end{array}$ & ICAM-1 & Microvasculature & $\begin{array}{l}\text { Serotec } \S \\
\text { Immunotec }\end{array}$ \\
\hline E-selectin & E-selectin & Microvasculature & Sanbio \\
\hline P-selectin & P-selectin & Microvasculature & \\
\hline VCAM & VCAM & Microvasculature & \\
\hline
\end{tabular}

ICAM: intracellular adhesion molecule; VCAM: vascular adhesion molecule. *: High Wycombe, Bucks, UK; +: Oxford, UK; \#: University of Southampton, UK; $\ddagger$ : Loughborough, UK; §: Kidlington, UK; $\uparrow$ : Marseille, France. 
cribed previously [11]. Details of monoclonal antibodies used for immunostaining are given in table 1 .

Quantification of inflammatory markers in sections was performed using the standard protocol as described by MoNTEFoRT et al. [6]. Immunostained cells were counted separately in the epithelium and submucosa. Areas including smooth muscle, glands, large blood vessels, torn and folded tissue were not included. The length of the epithelium and area of submucosa were determined using "Color Vision Software" (Improvision, UK) computer-assisted image analysis and results of inflammatory cell numbers were expressed as cells $\cdot \mathrm{mm}^{-1}$ and cells $\cdot \mathrm{mm}^{-2}$ in the epi-thelium and submucosa, respectively. Quantification of adhesion molecules in the submucosa was undertaken by expressing the number of vessels staining with specific antiadhesion antibody in the section as a percentage of the total number of blood vessels staining with pan-vessel marker EN4 in the adjacent section.

Flow cytometry. Flow cytometry was performed using a standard protocol described previously [12]. BAL cells were resuspended at $1 \times 10^{6}$ cells $\cdot \mathrm{mL}^{-1}$, and $100 \mu \mathrm{L}$ of this suspension was added to each FACS tube containing peridin chlorophyll-protein conjugate (CD3PerCP) and CD4 or CD8 fluoroscein isothiocyanate (FITC), together with CD25 PE (phycoerythrin); $100 \mu \mathrm{L}$ was also added to a tube containing T-cell receptor (TCR) $\alpha \beta$ FITC and TCR $\gamma \delta$ PE. Cells were incubated for $30 \mathrm{~min}$ at room temperature in the dark. BAL cells were washed once in PBS. Threecolour analysis was performed on a Becton Dickinson FACS scan using lysis II software. The results were recorded as total CD3, T-cell $\alpha \beta$ and $\gamma \delta$ cells per 10,000 events. CD4 and CD8 were expressed as the percentage of total CD3 T-cells. CD25 were expressed as the percentage of CD4+ and CD8+ T-cells, respectively. Monoclonal antibodies against T-cell markers CD3, CD4, CD8, CD25 were purchased from Becton Dickinson while TCR $\alpha \beta$ and $\gamma \delta$ monoclonal antibodies were purchased from T-cell Sciences (Woburn, MA, USA).
Statistical analyses. As the data were not normally distributed, Wilcoxon's paired sign rank test was used to compare the inflammatory indices in the BAL fluid and biopsies between the 2 days. Spearman rank correlations were performed to study the association between the percentage of PMNs and IL-8 in BAL fluid, and the percentage of PMNs and Gro- $\alpha$ in BAL fluid.

\section{Results}

\section{Bronchoalveolar lavage fluid}

Total and differential cell counts. As reported previously [8], there was no change in the total number of leukocytes between the two exposures. After ozone exposure there was a threefold increase in the proportion of neutrophils and epithelial cells with reciprocal changes in macrophages (table 2).

Soluble mediators. At $6 \mathrm{~h}$ after exposures no significant changes were detectable in myeloperoxidase, histamine and tryptase. However, there was a 1.8-fold increase in Gro- $\alpha$ (median (interquartile range (IQR)): 369 (165-679) vs 653 (273-1057) $\left.\mathrm{pg} \cdot \mathrm{mL}^{-1}, \mathrm{p}=0.05\right)$, a fourfold increase in total IL-8 (median (IQR): 7.5 (6-16.1) vs 27.8 (7.3-37.4) $\left.\mathrm{pg} \cdot \mathrm{mL}^{-1}, \mathrm{p}=0.01\right)$ and a trend towards an increase in total protein (median (IQR): 0.15 (0.08-0.27) vs 0.24 (0.2-0.37), $\mathrm{p}=0.058$ ) following ozone exposure (table 3, fig. 1a and b). Significant correlations were demonstrable between levels of PMNs and Gro- $\alpha(\mathrm{r}=0.80, \mathrm{p}=0.015)$ and between PMN and total IL-8 ( $r=0.71, p=0.047)$ in BAL fluid following exposure to ozone (fig. $2 \mathrm{a}$ and $\mathrm{b}$ ).

Bronchial biopsies. Ring staining was observed with antiCD3, -CD4, -CD8 and -CD25 antibodies demonstrating the surface expression of receptors. Mast cells were stained on account of the high concentration of immunoreactive tryptase within their cytoplasmic granules. Neutrophils also showed cytoplasmic staining for elastase. The mono-

Table 2. - Analysis of total and differential cell count in bronchoalveolar lavage fluid

\begin{tabular}{|c|c|c|c|c|c|c|}
\hline & $\begin{array}{l}\text { Total lymphocytes } \\
\times 10^{6} \text { cells } \cdot \mathrm{mL}^{-1}\end{array}$ & $\begin{array}{c}\text { Macrophages } \\
\%\end{array}$ & $\begin{array}{c}\text { Neutrophils } \\
\%\end{array}$ & $\begin{array}{c}\text { Eosinophils } \\
\%\end{array}$ & $\begin{array}{c}\text { Lymphocytes } \\
\%\end{array}$ & $\begin{array}{c}\text { Epithelial cells } \\
\%\end{array}$ \\
\hline Air & $0.21 \quad(0.1-0.3)$ & $90.6(88.1-93.1)$ & $(2-5.3)$ & $0(0-0.2)$ & $3.6(1.9-5.7)$ & $1.6(1.3-3.4)$ \\
\hline Ozone & $0.12(0.09-0.19)$ & $80.3(74.9-87.6)$ & $9.8(4.2-16.3)$ & $0(0-0.4)$ & $3.1(1.5-4.2)$ & $5 \quad(2.2-9.8)$ \\
\hline $\begin{array}{l}\text { p-value* } \\
(\mathrm{n}=8)\end{array}$ & NS & $<0.05$ & 0.07 & NS & NS & 0.05 \\
\hline
\end{tabular}

All air and ozone values represent median with interquartile range in parentheses. *: Wilcoxon's matched paired rank test. ss: nonsignificant. (See also Ref. [8]).

Table 3. - Concentrations of soluble mediators in bronchoalveolar lavage fluid

\begin{tabular}{llllcc}
\hline \multicolumn{1}{c}{ Mediator } & $\mathrm{n}$ & \multicolumn{2}{c}{ Air } & Ozone & p-value* \\
\hline Total protein $\mathrm{mg} \cdot \mathrm{mL}^{-1}$ & 8 & 0.15 & $(0.08-0.27)$ & $0.24(0.2-0.37)$ & 0.058 \\
IL-8 $\mathrm{pg} \cdot \mathrm{mL}-1$ & 9 & 7.5 & $(6-16.1)$ & $27.8(7.3-37.4)$ & 0.01 \\
Gro- $\alpha \mathrm{pg} \cdot \mathrm{mL}^{-1}$ & 9 & 369 & $(165-379)$ & $653(273-1057)$ & 0.05 \\
Histamine $\mathrm{nM} \cdot \mathrm{L}^{-1}$ & 9 & 1 & $(0.15-5.6)$ & $2.7(0-6.4)$ & 0.36 \\
Myeloperoxidase $\mu \mathrm{g} \cdot \mathrm{L}^{-1}$ & 9 & $3.3(1.75-8)$ & $4.1(2.05-28.05)$ & 0.20 \\
Tryptase U.L-1 & 9 & $0.48(0.23-0.78)$ & $0.55(0.2-0.78)$ & 0.67
\end{tabular}

All values represent median with interquartile range in parentheses. *: Wilcoxon's matched paired sign rank test. IL-8: interleukin-8; Gro- $\alpha$ : growth-related oncogene- $\alpha$. 
clonal antibodie EN4 clearly picked out the endothelium of the microvasculature. The monoclonal antibodies directed against P-selectin, E-selectin, ICAM-1 and VCAM-1 easily identified mucosal vasculature but between the antibodies there was a considerable difference in the proportion of vessels stained (table 4). Anti-ICAM-1 occasionally produced scant staining of the basal layer of the bronchial epithelium and also occasional mucosal leukocytes.

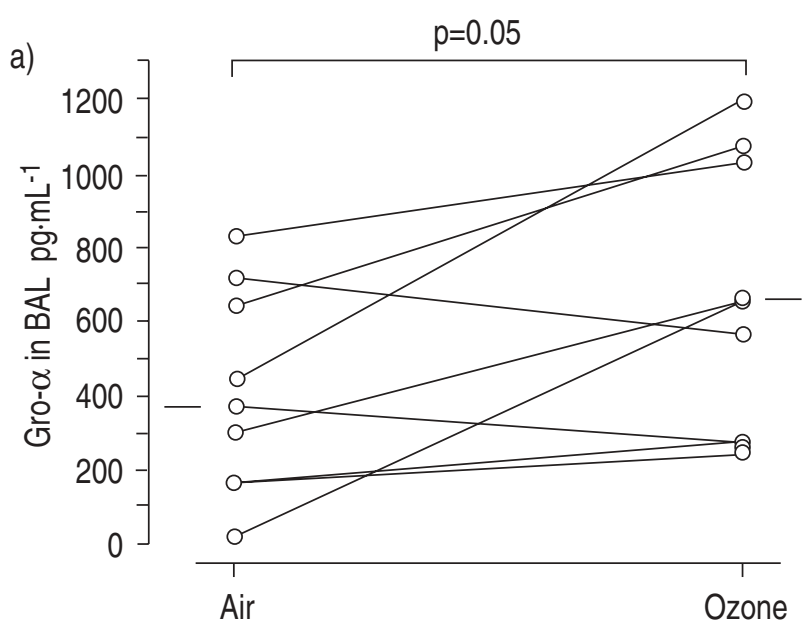

No significant changes were seen in neutrophils, mast cells, total T-cells (CD3+), T-cell subsets (CD4+, CD8+), the $\mathrm{CD} 4+/ \mathrm{CD} 8+$ ratio and activation marker CD25+ in the bronchial submucosa. Similarly, no changes were seen in the expression of vascular endothelial adhesion molecules, including P-selectin, E-selectin, ICAM-1 and VCAM-1 (table 4).

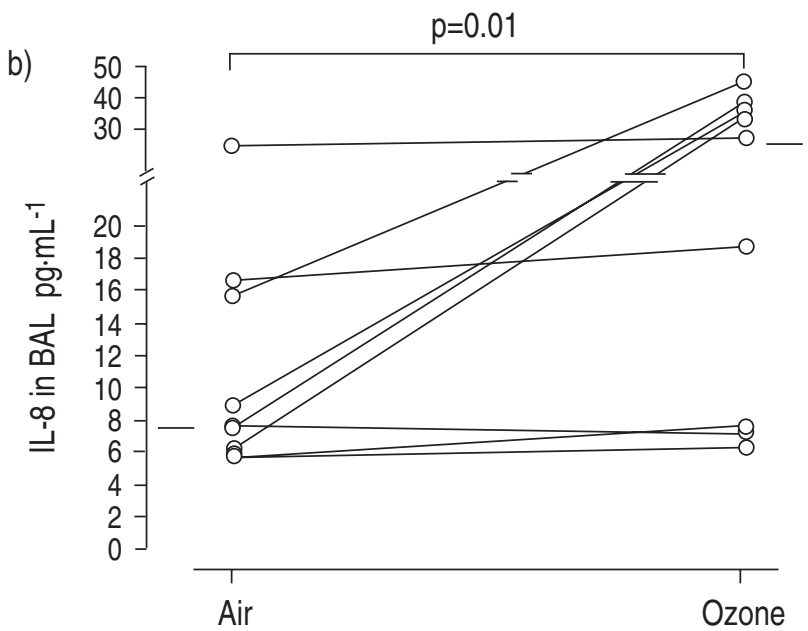

Fig. 1. - Concentration of: a) growth-related oncogene- $\alpha$ (Gro- $\alpha$ ); and b) interleukin (IL)- 8 in bronchoalveolar lavage (BAL) fluid following exposure to filtered air or ozone. Horizontal lines represent medians. Statistical assessment by Wilcoxon test. Significant differences between groups: a) $\mathrm{p}=0.05$ $(n=9) ; b) p=0.01(n=9)$.
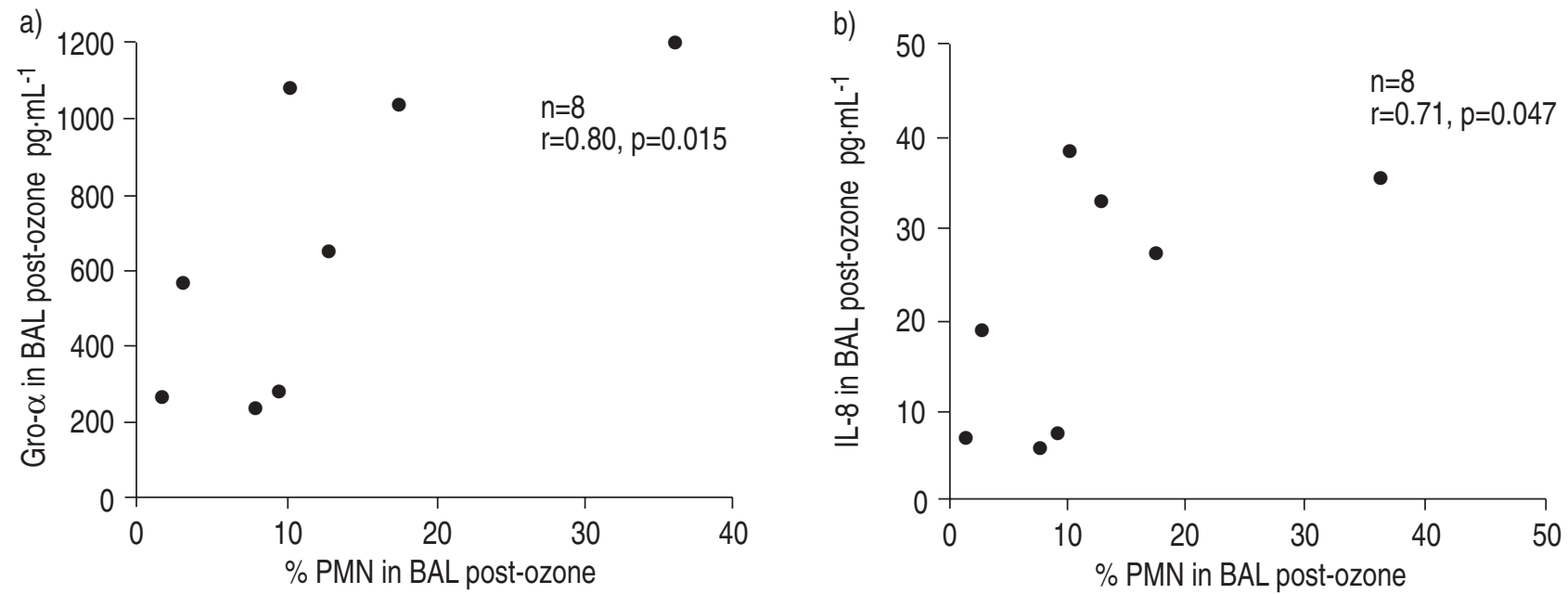

Fig. 2. - Correlations between: a) growth-related oncogene- $\alpha$ (Gro- $\alpha$ ) and per cent polymorphonuclear neutrophils (PMN) and b) interleukin (IL)- 8 and per cent PMN. BAL: bronchoalveolar lavage. Statistical assessment by Spearman rank correlation. Significant correlations between groups: a) r=0.80, $\mathrm{p}=0.015(\mathrm{n}=8)$; b $) \mathrm{r}=0.71, \mathrm{p}=0.047(\mathrm{n}=8)$.

Table 4. - Inflammatory indices in bronchial submucosa

\begin{tabular}{|c|c|c|c|c|}
\hline $\mathrm{mAB}$ & $\mathrm{n}$ & Air & Ozone & p-value* \\
\hline Neutrophil elastase cells $\cdot \mathrm{mm}^{-2}$ & 8 & $75.9(23.5-268.7)$ & $80.3 \quad(62.6-160)$ & 0.78 \\
\hline CD3 cells $\cdot \mathrm{mm}^{-2}$ & 8 & $86.8 \quad(23-179)$ & $122.33(12.6-198.6)$ & 0.58 \\
\hline $\mathrm{CD} 4$ cells $\cdot \mathrm{mm}^{-2}$ & 8 & $(14-104.8)$ & $53.4 \quad(4.2-93.1)$ & 0.73 \\
\hline $\mathrm{CD} 8$ cells $\cdot \mathrm{mm}^{-2}$ & 8 & $(9.2-57)$ & $(2.8-105.9)$ & 0.67 \\
\hline $\mathrm{CD} 25$ cells $\cdot \mathrm{mm}^{-2}$ & 8 & $0 \quad(0-0.3)$ & $(0-0.6)$ & 0.46 \\
\hline Mast cells cells $\cdot \mathrm{mm}^{-2}$ & 7 & $35.6(14.6-39.8)$ & $(12.3-56.5)$ & 0.13 \\
\hline ICAM-1 \% & 9 & $86 \quad(71-100)$ & $(66.5-98.5)$ & 0.55 \\
\hline P-selectin \% & 9 & $(10-67.5)$ & $(5.5-47)$ & 0.44 \\
\hline E-selectin \% & 9 & $(12-67.5)$ & $(8.5-53)$ & 0.77 \\
\hline VCAM \% & 9 & $1 \quad(0-10.5)$ & $4 \quad(0-10)$ & 0.86 \\
\hline CD4/CD8 ratio & 8 & $1.5(0.61-2)$ & $0.86(0.67-3.1)$ & 0.75 \\
\hline
\end{tabular}

All values represent median with interquartile range in parentheses. *: Wilcoxon's matched paired sign rank test. mAB: monoclonal antibody; ICAM: intracellular adhesion molecule; VCAM: vascular cell adhesion molecule. 
Table 5. - Analysis of T-lymphocytes in bronchoalveolar lavage (BAL) fluid by flow cytometry

\begin{tabular}{|c|c|c|c|c|c|}
\hline $\mathrm{mAB}$ & $\mathrm{n}$ & Air & & zone & p-value* \\
\hline CD3·10,000 total BAL cells-1 & 9 & $513(344-761)$ & 143 & $(73-566)$ & 0.09 \\
\hline TCR $\alpha \beta \cdot 10,000$ total BAL cells- & 9 & $501(325-775)$ & 189 & $(155-522)$ & 0.07 \\
\hline TCR $\gamma \delta \cdot 10,000$ total BAL cells ${ }^{-1}$ & 9 & $11 \quad(0-58)$ & 20 & $(14-27)$ & 0.87 \\
\hline CD4 \% of CD3 & 9 & $54 \quad(49-64)$ & 53 & $(39-61)$ & 0.21 \\
\hline $\mathrm{CD} 8 \%$ of CD3 & 9 & $34 \quad(28-42)$ & 45 & $(31-48)$ & 0.17 \\
\hline Activated CD4+ T-cells \% & 9 & $26(18-32)$ & 14 & $(7-22)$ & 0.01 \\
\hline Activated CD8+ T-cells \% & 8 & $7 \quad(4-13)$ & 2 & $(0.4-7)$ & 0.04 \\
\hline CD4/CD8 ratio & 9 & $1.6(1-2)$ & 1 & $(0.8-1.6)$ & 0.05 \\
\hline
\end{tabular}

All values represent median with interquartile range in parentheses. *: Wilcoxon's matched paired sign rank test. mAB: monoclonal antibody; TCR: T-cell receptor.
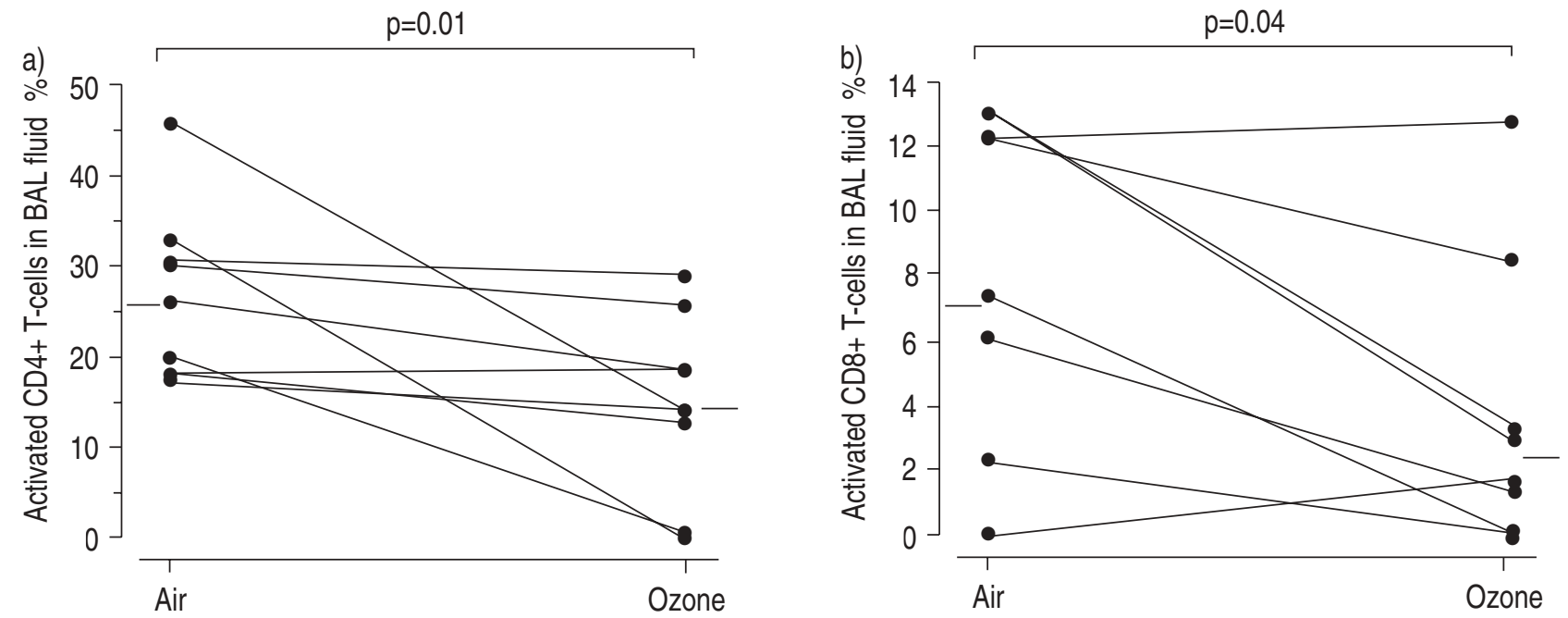

Fig. 3. - Percentage of bronchoalveolar lavage (BAL) a) CD4+ and b) CD8+ T-cells expressing CD25 following exposure to filtered air or ozone. Horizontal lines represent medians. Statistical assessment by Wilcoxon test. Significant differences between groups: a) $\mathrm{p}=0.01(\mathrm{n}=9)$; $\mathrm{b}) \mathrm{p}=0.04(\mathrm{n}=8)$.

Flow cytometry. After ozone exposure there was a significant decrease in the proportion of activated (CD25+) T-cells in BAL fluid. This decrease was apparent in both the CD4+ and CD8+ T-cell subsets (table 5, fig. 3a and b). The CD4/ CD8 ratio altered in favour of CD8 cells (median values of 1 after ozone $v s 1.6$ after air) and there was a trend towards a decreased proportion of CD3+ cells in BAL fluid.

\section{Discussion}

The present data show that short-term exposure to 0.2 ppm ozone induces epithelial shedding, neutrophil recruitment, an increase in the $\mathrm{C}-\mathrm{X}-\mathrm{C}$ chemokines Gro- $\alpha$ and IL-8 in BAL fluid, and decrements in T-cell numbers, activation markers and the $\mathrm{CD} 4+/ \mathrm{CD} 8+$ ratio in BAL fluid. However, no changes were seen in any of the inflammatory cells or adhesion molecules examined in the submucosa of biopsies following exposure to ozone.

The exposure system used in this study has been carefully standardized and validated. The concentration of 0.2 ppm represents peak ozone levels encountered during summertime air pollution episodes. A minute ventilation rate of $30 \mathrm{~L} \cdot \mathrm{min}^{-1}$ was chosen in order to simulate mild outdoor activity and the sampling time of $6 \mathrm{~h}$ was chosen because inflammatory response to ozone has been reported to peak between 6-10 h after short-term exposures [13].
Previous studies have shown that ozone induces a significant airway inflammatory response in both proximal and distal airways of healthy subjects [2,3]. ARIs et al. [3] reported neutrophilia in biopsies taken from proximal airways of healthy subjects $18 \mathrm{~h}$ after exposure to $0.2 \mathrm{ppm}$ ozone for $4 \mathrm{~h}$ and, more recently, ARIs et al. [14] have shown increased expression of ICAM-1 in the microvascular endothelium of the bronchial submucosa of healthy human volunteers $18 \mathrm{~h}$ after short-term exposure to ozone, thus highlighting the role of ICAM-1 in PMN recruitment. In addition, increased expression of P-selectin was reported in the vascular endothelium of the bronchial submucosa of healthy Swedish subjects $1.5 \mathrm{~h}$ after exposure to a lower concentration of ozone ( $0.12 \mathrm{ppm}$ for $2 \mathrm{~h}$ ) [5]. Data from in vitro studies suggest that the expression of E-selectin and ICAM-1 peaks 3-4 and 12-18 h, respectively following stimulation with agents such as histamine, thrombin, oxygen radicals and tumour necrosis factor (TNF)- $\alpha$ [15-19]. However, in the present study neither tissue neutrophilia nor upregulation of E-selectin and ICAM-1 was found in the proximal airway biopsies.

The absence of PMN influx in the bronchial submucosa in the present study could be due to the relatively lower dose of ozone and early sampling time employed in this study. Given that the proximal alveolar region is the major site for the deposition of ozone [20,21], the trend towards neutrophilia and chemokine responses seen in BAL fluid probably represents a peripheral airway response. Since approximately $40-45 \%$ of inhaled ozone is deposited in 
the proximal airways (at the level of bronchus intermedius) it is plausible that the effective dose of ozone might have been too low to elicit an inflammatory response in the proximal airways in the present study. In addition, it is likely that, owing to differential deposition of ozone in the respiratory tract, the kinetics of the inflammatory response are different between proximal and distal airways and the time point of $6 \mathrm{~h}$ may thus have been too early to detect PMN influx in the proximal airways.

In the context of the neutrophil response, an interesting observation seen in this study is an increase in Gro- $\alpha$, a C-X-C chemokine known to exhibit a significant chemotactic property for PMNs and also to induce granule exocytosis, weak respiratory bursts and transient elevations in cytosolic calcium [22, 23]. VILLARD et al. [24] recently showed that Gro- $\alpha$ is probably as important as IL- 8 in the pathogenesis of acute lung injury in patients with adult respiratory distress syndrome, bacterial pneumonia or Pneumocystis carinii pneumonia. In that study, significant correlations were found between levels of Gro- $\alpha$ and absolute numbers of PMN in BAL fluid. In the present study there was a significant positive correlation between levels of Gro- $\alpha$ and PMN in BAL fluid, suggesting that this chemokine could play a key role in the acute inflammatory response to ozone.

Similarly, a significant increase was seen in total IL-8 (immunoreactive) in all subjects in BAL fluid following exposure to ozone in this study. Elevated concentrations of this $\mathrm{C}-\mathrm{X}-\mathrm{C}$ chemokine have been reported in healthy and asthmatic airways in both bronchial wash and BAL fluid after ozone exposure $[25,26]$. IL- 8 is the most prominent member of the $\mathrm{C}-\mathrm{X}-\mathrm{C}$ family and is reported to cause the release of lysosomal enzymes from neutrophils, to increase the adherence of neutrophils to unstimulated endothelial cells, fibrinogen and matrix proteins, to increase granulocyte surface expression of Mac-1 (CD11/ CD18), to induce L-selectin shedding from leukocytes and to upregulate the $\beta_{2}$-integrin subunit [22]. Although a number of cell types produces IL-8, including monocytes, alveolar macrophages, fibroblasts, lymphocytes, epithelial cells, endothelial cells and neutrophils, it is most likely that epithelial cells are the major source in response to ozone since they are adjacent to the airway lumen [22]. Significant positive correlations between IL- 8 and Gro- $\alpha$ and the percentage of PMN in BAL fluid suggest that these $\mathrm{C}-\mathrm{X}-\mathrm{C}$ chemokines are important in the early inflammatory response to ozone.

The present data on the effects of ozone on T-lymphocytes are novel. Effects were observed that were mainly confined to the BAL compartment, since no corresponding changes were found in the total T-cells, their subsets or CD25 expression in the biopsies. In contrast to the original hypothesis, there was a significant decrease in the proportion of activated CD4+ (T-helper) and activated CD8+ (T-cytotoxic/suppressor) cells. In addition, the $\mathrm{CD} 4 / \mathrm{CD} 8$ ratio decreased after exposure to ozone, probably through a relative increase in CD8+ cells. The absence of any corresponding change in T-cell numbers in the bronchial biopsies following ozone exposure suggests that these changes take place more in the peripheral airways, once again reiterating the concept that the kinetics of airway inflammation are probably different in proximal and distal airways.
Bleavins et al. [7] have also suggested that T-cells may play a regulatory response in ozone induced airway inflammation. In their study, when CD-1 mice were exposed repeatedly to ozone in the presence of cyclosporin A, the number of T-lymphocytes had halved by day 14 of the exposure, as opposed to the placebo group (ozone plus vehicle). In addition, the cyclosporin group developed a significantly greater inflammatory response than the control group as gauged by the number of PMNs and "lesion volume". These observations suggest that T-lymphocytes could play a protective role in the airway inflammatory response to ozone, particularly following repeated exposures.

In conclusion, short-term exposure of healthy humans to $0.2 \mathrm{ppm}$ ozone with intermittent moderate exercise induces neutrophil influx in the peripheral airways at $6 \mathrm{~h}$ but no apparent inflammatory response in the proximal airways. This response seems to be mediated, at least in part, by chemokines, including interleukin- 8 and growthrelated oncogene- $\alpha$. In addition, such an exposure has an effect on T-cell subsets and activation, the significance of which is unclear at the present time. These findings confirm the ability of a moderate to high concentration of ozone to induce airway inflammation, and indicate a pattern that is both localized and distinct from the inflammatory responses that have been described in asthma and other related airway diseases.

Acknowledgements: The authors are grateful to J. Somerville for his technical assistance and G. Wintrell for processing the BAL fluid.

\section{References}

1. Koren HS, Devlin RB, Graham DE, et al. Ozone induced inflammation in the lower airways of human subjects. Am Rev Respir Dis 1989; 139: 407-415.

2. Devlin RB, McDonnell WF, Mann R, et al. Exposure of humans to ambient ozone for 6.6 hours causes cellular and biochemical changes in the lung. Am J Respir Cell Mol Biol 1991; 4: 72-81

3. Aris RM, Christian C, Hearne PQ, Kerr K, Finkbeiner WE, Balmes JR. Ozone induced airway inflammation in human subjects as determined by airway lavage and biopsy. Am Rev Respir Dis 1993; 148: 1363-1372.

4. Carlos TM, Harlan JM. Leukocyte-endothelial adhesion molecules. Blood 1994; 84: 2068-2101.

5. Krishna MT, Blomberg A, Biscione GL, et al. Short-term ozone exposure upregulates P-selectin in normal human airways. Am J Respir Crit Care Med 1997; 155: 17981803.

6. Montefort S, Gratziou C, Goulding D, et al. Bronchial biopsy evidence for leucocyte infiltration and upregulation of leucocyte-endothelial adhesion molecules 6 hours after local allergen challenge of sensitised asthmatic airways. J Clin Invest 1994; 93: 1411-1421.

7. Bleavins MR, Sargent NE, Dziedzic D. Effect of cyclosporin A on ozone induced pulmonary lesion formation: pharmacological elimination of T-lymphocyte regulatory response. Arch Environ Contam Toxicol 1995; 28: 240247.

8. Krishna MT, Springall DR, Meng QH, et al. Effects of ozone on epithelium and sensory nerves in the bronchial mucosa of healthy humans. Am J Respir Crit Care Med 1997; 156: 943-950. 
9. Lowry OH, Rosebrough NJ, Farr AL, Randall RJ. Protein measurement with the phenol reagent. J Biol Chem 1951; 193: 265-275.

10. Smith PK, Krohn RI, Hermanson GT, et al. Measurement of protein using bicinchoninic acid. Anal Biochem 1985; 150: 76-85.

11. Britten KM, Howarth PH, Roche WR. Immunohistochemistry on resin sections: a comparison of resin embedding techniques on small mucosal biopsies. Biotech Histochem 1993; 68: 271-280.

12. Krug N, Madden J, Redington AK, et al. T-Cell cytokine profile evaluated at single cell level in BAL and blood in allergic asthma. Am J Respir Cell Mol Biol 1996; 14: 319-326.

13. Schelegle ES, Siefken AD, McDonald R. Time course of ozone induced neutrophilia in normal humans. Am Rev Respir Dis 1991; 43: 1353-1358.

14. Aris R, Ferrando R, Chen LC, Christian D, Balmes JR. Increased ICAM expression on human bronchial epithelium after acute exposure to ozone. Am J Respir Crit Care Med 1995; 151: A26.

15. Bevilacqua MP, Pober JS, Wheeler ME, Cotran RS, Gimbrone MA Jr. Interleukin 1 acts on cultured human vascular endothelium to increase the adhesion of polymorphonuclear leukocytes, monocytes, and related leukocyte cell lines. J Clin Invest 1985; 76: 2003-2011.

16. Pober JS, Bevilacqua MP, Mendrick DL, Lapierre LA, Fiers W, Gimbrone MA Jr. Two distinct monokines, interleukin 1 and tumor necrosis factor, independently induce biosynthesis and transient expression of same antigen on the surface of cultured human vascular endothelial cells. $J$ Immunol 1986; 136: 1680-1687.

17. Pober JSM, Gimbrone MA Jr, Lapierre LA, et al. Overlapping patterns of human endothelial cells by interleukin 1, tumor necrosis factor, and immune interferon. J Immunol 1986; 137: 1893-1896.
18. Rice GE, Bevilacqua MP. An inducible endothelial cell surface glycoprotein mediates melanoma adhesion. Science 1989; 246: 1303-1306.

19. Masinovsky B, Urdal D, Gallatin WM. IL-4 acts synergistically with IL- $1 \beta$ to promote lymphocyte adhesion to microvascular endothelium by induction of vascular cell adhesion molecule-1. J Immunol 1990; 145: 28862895.

20. Hu SC, Ben-Jebria A, Ultman JS. Longitudinal distribution of ozone absorption in the lung. Quiet respiration in healthy subjects. J Appl Physiol 1992; 73: 1665-1661.

21. Gerrity TR, Biscardi F, Strong A, et al. Bronchoscopic determination of ozone uptake in humans. $J$ Appl Physiol 1995; 79: 852-860.

22. Teran LM, Davies DE. The chemokines: Their potential role in allergic inflammation. Clin Exp Allergy 1996; 26 : 1005-1019.

23. Teran LM, Carroll MP, Frew AT, et al. Leukocyte recruitment after endobronchial allergen challenge in asthma. Relationship to procedure and airway interleukin-8 release. Am J Respir Crit Care Med 1996; 154: 469-476.

24. Villard J, DayerPastore F, Hamacher J, Aubert JD, Schlegelharrater S, Nichod LP. Gro-alpha and interleukin-8 in pneumocystis carinii or bacterial pneumonia and acute respiratory distress syndrome. Am J Respir Crit Care Med 1995; 152: 1549-1554.

25. Balmes JR, Chen LL, Scannell C, et al. Ozone-induced decrements in FEV1 and FVC do not correlate with measures of inflammation. Am J Respir Crit Care Med 1996; 153: 904-909.

26. Scannell C, Chen L, Aris RM, et al. Greater ozoneinduced inflammatory responses in subjects with asthma. Am J Respir Crit Care Med 1996; 154: 24-29. 